\title{
Speaking, Silence, and Shifting Listening Space: The NWSA Lesbian Caucus in the Early Years
}

\author{
TUCKER FARLEY
}

The NWSA Lesbian Caucus was founded in a burst of positive energy which nurtured and shaped the organization. Structural tensions between regions, the newsletter, and caucus constituencies provided a ground upon which discourses of homophobia and racism became manifest in the early years of the National Women's Studies Association (NWSA). Women in the Third World Women's Caucus and the Lesbian Caucus had difficulty with the association and with working together. Questions of representation, giving voice, and divisiveness all needed to be dealt with at the same time as building a strong caucus presence. As advocates, the Lesbian Caucus worked to represent lesbians and confront homophobia within the association, as well as to make the concerns and lives of lesbians more visible in Women's Studies, the academy, and the public sphere, with mixed success. Our experience in the early years points to the ways that listening space is shaped discursively, and the ways discourses, embodied in the gut, shape perceptions of reality. The essay explores how caucus constituencies faced contradictions of identity politics before there was a language for them.

The high point of the NWSA Lesbian Caucus may well have been its dramatic emergence at the 1977 NWSA founding convention in San Francisco. Student and faculty representatives mounted the podium to demonstrate to the assembly that lesbians, both those open and those forced into closets even within the women's liberation movement, defied stereotypes and deserved organizational representation in our diversity: we were women from all ranks and races, all professional and political persuasions. In the swelling ranks of women's studies activists, many lesbians were leaders, though too many-fearing for their jobs and reputation, for their housing, and for their children-found themselves, in the language of the day, doubly oppressed, and some were silenced. Would the newly forming NWSA condone strong lesbian advocacy? And would its members endorse strong lesbian constituency representation in the Coordinating Council (CC)? The call rang out: "To show this body the diversity of those living a lesbian lifestyle, we call on those who can to rise." ${ }^{\prime 1}$

In the hush that followed, silence grew loud. From my perspective on the podium I could look out at the whole room, crowded with women, their faces upturned, startled. Would anyone rise? One woman rose. Then another. We held our breaths. Then two more; one by one women rose in the room and stood, turning to see who else had dared to rise: you? Then 
more! They did not stop: they kept rising, a sea of women rising and standing. Moved and delighted, we burst into applause, clapping wildly to honor the courage, the commitment, and the promise of these women, a rising tide rejecting invisibility.

The resolution carried. Passing the torch a few years later, I wrote around 1980 to the next generation of lesbian caucus activists who were asking about our history and procedures: "We agreed to elect a variety of representatives to reflect the diversity of our membership, and to help NWSA ensure the committees, governance and material reflect these constituencies: lesbian Third World/Woman of Color; lesbian student; lesbian community (non-academic/institutionally based project or program); lesbian academic. We have said all elected representatives and spokeswomen should be out lesbians." 2

As founders of NWSA, we envisioned an organization committed to feminist education in all educational settings and on all levels. The philosophy was consistent with, and the language reminiscent of, the New University Conference, the radical national organization in which many of us in academia on the left had been participating, especially after the demise of Students for a Democratic Society. As inheritors of the 1960s spirit of participatory democracy, we believed that the resources of the academy should be made more widely available to the people, and should serve them in a broader range of settings than they had historically done. This drive was important in building a broad-based, radical movement. As its arms became institutionalized, as was now beginning to happen with Women's Studies, that radical impetus was met with a need to prove legitimacy, a need that eventually overcame the early, exciting days of cooperative Women's Studies where women from the communities and from the academies worked closely together in developing Women's Studies as the academic arm of the women's liberation movement.

NWSA must openly advocate for all women-in theory this goal was indisputable. But how to accomplish the goal? Given the realities of homophobia and racism within the movement, both women of color (then self-named Third World women) and, as it turned out, lesbians were vocal in pushing the new association into organizational responsibility by constituency as well as region, a structural model that lasted until the constitutional revisions of 1992 and $1999 .{ }^{3}$ As we celebrate the twentyfifth anniversary of NWSA, we might ask, have the caucuses functioned so effectively there is no further need for them? Have the contradictions of identity politics imploded? Has a national conservatism won a new foothold in feminism? Have new forms of advocacy and representation been developed? Are separate constituency structures unworkable? How can we think about the past in ways that inform the present and help us toward the future? I expect there are many answers and many more questions concerning the viability of constituency representation in organizations 
that start in liberation movements and, when successful, begin to enter the mainstream. This piece is a piece only-an effort to say some unsaid things ${ }^{4}$ to contribute to the quilting of the history of NWSA.

\section{Founding the Lesbian Caucus}

During the opening hours of the founding convention, as we met and drafted the details of the association we wished to propose, we heard that a male reporter covering the convention had denounced the new association as dominated by lesbians. Men as well as women attended the founding convention, some more and some less sensitive to the need for women to be the leaders in this endeavor, some more and most less habituated to leadership by women. Leadership by lesbians was a fact, though it was not only men who might not yet have learned to be comfortable with openly lesbian activists. In response, conference organizers downplayed lesbian presence. ${ }^{5}$ And a small note posted in the convention center, calling for an all-woman meeting, brought a range of women together. Was the note a code for lesbians? A separatist voice? A call for a consciousness-raising session? Perhaps those who showed up had no one agenda, but from the meeting emerged agreement to found a lesbian caucus inside the organization with the twin goals of advocating for all women in all educational settings and for lesbian visibility and rights within the organization itself.

As long as feminists could be threatened by lesbian-baiting and homophobia, the whole group, heterosexual and lesbian alike, would be susceptible to a brake: held back by fear, made more conservative by caution, and acting from weakness rather than building on strength. "The lesbian caucus worked in two ways. It helped those lesbians who were terrified to be more visible; and it moved the organization off dead center," Toni McNaron recalls. "If the lesbian caucus hadn't been as strong and clear as it was the NWSA couldn't have gotten off the ground" (2001). Theoretically, everyone at the founding convention wanted to resist tactics of divide and conquer and build an inclusive association; still, divisions work in multiple ways, and can be assessed and experienced differently and in shifting ways-all of which happened in the early years of the NWSA Lesbian Caucus.

During the San Francisco founding convention, the Lesbian Caucus met and elected four representatives, from specific constituencies, to the newly established CC: Susan Cayleff, student from Sarah Lawrence; Tucker Farley, faculty and women's studies administrator from Brooklyn; Elisa Buenaventura, Third World woman and student from Boston and Colombia; Toni McNaron, community educator from Maidenrock Institute in Minnesota and teacher. In a rump session outdoors in the evening after the conference proper was over, as a start up measure I nominated Sylvia 
Gonzales, a West Coast delegate from the Third World Women's Caucus, to operate an interim national office; a student from the Lesbian Caucus, Anne Elizabeth, volunteered to help. Patricia Bell Scott and Evelyn Torton Beck were to co-chair the first CC meeting, where representatives from the caucuses and regions would come together for the first time as the governing body of the now-founded NWSA. ${ }^{6}$ The association was still on paper, but beginning to take shape; collectively and across distance, we had the task of inventing it and making it work.

Despite all the excitement of coming together and building for the future, and despite a desire for unity and mutual support, historic social tensions immediately flared. No sooner had the Lesbian Caucus been established, than some representatives from the Third World Women's Caucus claimed that their caucus would represent Third World lesbians. Some also claimed that while the Third World Women's Caucus needed four seats on the CC to represent different racial groups within the caucus, different constituencies from the Lesbian Caucus were not as legitimate. Were the lesbians, hungry for the power of four seats such as the Third World Women's Caucus had asked for, copying them? In the crossfire, those most pressured were those who could claim membership in both caucuses and were out of the closet. In the Lesbian Caucus, Elisa Buenaventura was to be caught in the middle. As one of the four elected Lesbian Caucus representatives, she participated actively during the spring and summer in the effort to advocate for lesbian concerns within the association, especially around efforts to secure lesbian representation in the association newsletter, and to have a lesbian voice in the national and association press in public response to public lesbian-bashing.

NWSA was from its inception called upon to defend Women's Studies from lesbian-baiting, beginning with the media attack in January at the founding convention in California, and following. In late winter, The New York Times Magazine published a vitriolic piece by Anne Roiphe, "The Trouble at Sarah Lawrence" (20 March 1977), scapegoating lesbians. I wrote a letter to the NYT editor as Lesbian Caucus Representative to the NWSA Coordinating Council, but neither this letter, nor one written some time later by Sylvia Gonzales, was printed. ${ }^{7}$ Members of the Lesbian Caucus looked forward to responding in the "NWSA Newsletter," a section, funded by NWSA, of the Women's Studies Newsletter published by Florence Howe out of SUNY-Old Westbury. ${ }^{8}$ But Howe and two other women wrote the response which was to be published in the newsletter. To my argument that an out lesbian voice from the NWSA Lesbian Caucus ought to be included, Howe replied that the response was "a packet and can't be broken up" (1977). . It was a difficult moment for the new Lesbian Caucus; eager to believe that we could participate fully in the new association, we were unable to understand the logic of such an exclusionary stance. 
During the spring and summer, members of the caucus made several unsuccessful efforts to ensure that there would be materials from lesbians in the "NWSA Newsletter" section of the Women's Studies Newsletter. Susan Brown, Elisa Buenaventura, and Pat Gozemba wrote a Lesbian Caucus response for the newsletter, emphasizing both that the association must defend all women, and that all women must have a voice: "The responsibility for defending all women and advocating their issues in the women's studies movement must fall equally on all of us" (1977). The caucus asked that this piece be printed as the Lesbian Caucus column in the newsletter, but no such column was ever printed.

The newsletter formed an advisory committee to establish procedures and policies, and communicated with Lesbian Caucus member Anne Elizabeth, a part-time student in California. It was not clear why a student without travel funding would be expected to function in New York as liaison from the Lesbian Caucus, especially since Susan Cayleff was in New York and had been named by the caucus representatives to do the job. ${ }^{10}$ Unable to attend the meetings in New York, Anne Elizabeth felt ineffective as a member of the Newsletter Advisory Committee, and wrote the caucus reps about "Florence's decision to exclude lesbian-written material" (1977).$^{11}$ An article by Betsy Alexander, a founding member of the NWSA Lesbian Caucus and member of a lesbian research collective in the Boston area, was rejected. Printed and edited copies of Lesbian Caucus resolutions from the Milwaukee Coordinating Council Meeting in May were also sent to Howe, who, questioning the content, sent them back. ${ }^{12}$ In the caucus, lesbians felt beleaguered and excluded; in the editorial room, Howe felt her editorial process was not being respected (1977).

By the time of the first meeting of the CC, in May 1977, tensions were everywhere competing with a sense of possibility and an urgency to move forward. The difficulties of trying to run an association, build its caucuses and regions, and give it substance over long distances, with no money, on volunteer labor, without agreed upon practices or guidelines was taking its toll. Rumbles of dissatisfaction concerning the relative inactivity of the national office led the Third World Women's Caucus to support the resignation of Gonzales before any business was put before the council. The resignation was designed to protect Gonzales from criticism, and make any discussion of the national office moot. A steering committee was set up, but not before co-chairs Scott and Beck stopped functioning in that role. Several CC members present felt concerned that racism was not dealt with at the meeting, especially as Scott sat silent, and the meeting continued. Scott packed and left; returning to their dormitory room and finding Scott had gone, Beck also left.

When women from the Third World Women's Caucus stayed out in an extended dinner hour, those attending the evening meeting, including Buenaventura from the Lesbian Caucus, suspended the agenda-both 
from an unwillingness to proceed with association business absent so many women of color, and from the need to address racism. The first part of the evening was spent trying to figure out if the Third World Women's Caucus had staged a walkout, which led to a discussion of racism in the new association. Later in its history, the association adopted "stop action" and other procedures designed to recognize and attempt to deal with problems as they occurred. Members were designated to call a halt so a meeting could not proceed while a problem remained unresolved (as Barbara Gerber describes elsewhere in this issue). If the matter could not be handled simply, a stop sign was raised and business was halted in order for the body to attend to the concern being raised from the floor. But that day, we had no procedures in place, and political responses varied a good deal. Thus, when the women returned, little was solved.

Lesbian Caucus members were astonished to hear that Third World Women's Caucus members thought that the Lesbian Caucus had planned to fund Anne Elizabeth to attend the CC to give evidence against Gonzales. "There seemed to be some added tension between the Third World and Lesbian Caucus, apparently over fear that Anne Elizabeth was being used by the Lesbian Caucus to undermine Sylvia Gonzales' position which was in tension with Florence's position concerning the newsletter and finances" (Lesbian Caucus Newsletter 1977, 1). That the Lesbian Caucus should be perceived as part of the power structure and capable of such a financial expense, and that its opposition to Florence Howe's fiscal policies became reversed in this narrative, are both indications of a sense of powerlessness and some need for self-defense, traditionally benchmarks of oppression. In fact, both Gonzales and the Lesbian Caucus were opposed to shouldering significant financial obligations for Howe's newsletter at this time.

We were all caught up in a tangle of discourses-racism, homophobia, our media, finances, and power-in a new association, brought to birth before the growth of working relations, structural or procedural agreements, practices for dealing with multiple oppressions. The fledgling association was being tried from its inception, and only the earnest and committed efforts of those in every camp kept it going at all. I spent some time that Sunday with Sylvia Gonzales who then came into the meeting with a statement of unity. And back in New York, in the months following, I pursued Luvinia Pinson, who had chosen to stay in the Third World Women's Caucus and not participate in the Lesbian Caucus, to meet on ways to forge strong alliances between the two caucuses. If only we could have succeeded in doing that! But we did not then find the way. I have no doubt that there are many stories from many perspectives on these early birth pangs. They are not easy to tell. I believe it is especially difficult to speak, and to be heard, as an individual, before many voices have come together and begun to shift the listening spaces we inhabit. 
How we speak is a function of where we speak and of our experience with, and assumptions about, those listening and about how they hear us, how they might react to our speaking. Experientially, the "listening space" appears to us as a situation surrounding us and external to us, affecting us and how we speak, affecting what we feel we can and cannot say, even silencing us. When we feel we cannot speak out and be heard without jeopardizing our character in the minds of others important to the survival of our identity or some aspect of our public reputation; when we cannot trust others to hear us sympathetically; when our experience leads us to feel that others' ways of understanding are so different that they may even look down on us, scorn us, or judge us to be crazy-then we may not be able to speak, or we may not speak. Furthermore, these silences reinforce the very discourses we may wish to change. We build our public postures as well, perhaps, as our personal stances in relation to them. Our actions and identities may be shaped around silences in public and defenses behind the scenes. My own silence for two decades around many of these moments, being hurt and hurting others, makes it difficult to speak even now, knowing my view is a partial one. Particularly important it seems to me are the voices of lesbians of color.

Given the racism that operated within as well as outside the movements, and believing that it would be remiss not to give structural representation to Third World women in the Lesbian Caucus, the fall Lesbian Caucus Newsletter tried to balance support of lesbians in the Third World Women's Caucus with support of lesbians of color in the Lesbian Caucus. The former appeared primarily straight and the latter primarily white, with some overlapping membership in both caucuses. What were lesbians who identified in both groups to do? The newsletter did not help; meant as an effort to reach out to Third World lesbians who may have made the choice to be active primarily in the Third World Women's Caucus, it did not constitute strong support for Buenaventura, a Third World woman from Colombia who had chosen to be active in the Lesbian Caucus, of which she was a founding member. From Third World Women's Caucus members she faced taunts that she could not represent Third World women in the United States, as she was not raised here; that she had resided here for several years did not give her sufficient experience with racism in the United States. Although she herself agreed that she could not speak for all Third World women, she was accused of setting herself up to do so by occupying the slot for Third World women in the Lesbian Caucus delegation. This was a hot seat Buenaventura chose not to take. After the first $\mathrm{CC}$, according to letters of this period, Buenaventura described herself as the elected student representative from the Lesbian Caucus rather than as a Third World representative for the Lesbian Caucus (see Brown, Buenaventura, and Gozemba 1978; Buenaventura 1978). The limits of what 
was to be called identity politics became evident simultaneously with its emergence in NWSA. We foundered on the politics of representation before there was a language for it.

\section{Lesbian Studies and Activism Moves Forward}

As they developed in the 1970s, affirmative, woman-centered communities, cultures, and politics were exhilarating and became vital aspects of the women's movement. Yet, Lesbian Caucus members were also confronted during this period with the necessity of combating lesbian-baiting within the women's studies movement itself. Feminist speakers on Women's Studies were specifically targeting the presence of lesbians as a problem in organizing the women's studies movement. One example was The Feminist Scholarship Conference, which had taken place 28 February-3 March 1978 in Champaign, Illinois. At a session devoted to "The Problems in Women's Studies," the stated problems included: needy students who want counseling, not academic work; conflict between street Women's Studies and real Women's Studies; and-lesbians. Why lesbians? Because of lesbians, women's colleges were closing: Sarah Lawrence was in trouble, Bryn Mawr and Smith were to follow, those in comfortable niches were discomfited, and students were scared away from fear of being seduced. At the Maidenrock CC meeting in 1978, several people reported difficulty with this analysis put forward in Illinois. Outrage was so widespread on the part of Lesbian Caucus members that these concerns were included in my report to the Lesbian Caucus at its first national membership meeting at the 1979 NWSA Conference in Kansas (see Farley 1979a).

The Champaign session, however, presented a mainstream feminist analysis, not the radical analysis we expected of NWSA. In fact, lesbians were, at a subsequent $\mathrm{CC}$, given separate housing, which on the one hand accommodated homophobic anxiety and at the same time provided a more relaxed environment for lesbians. The move, acknowledging the presence of a contingent of lesbians, led the administration of the host school to threaten to sue the association and have us kicked out of the (Catholic) college.

On the Right, anti-gay initiatives were receiving enormous funding and generating a backlash in several states. The impact of this reactionary pressure was painfully felt in the women's movements, which experienced pressure to cut loose from or repudiate those elements which made progress in the mainstream harder. The atmosphere generated by the strong and organized right-wing forces of reaction, focused in key areas to repeal gains lesbians and gay men were making - as in Dade County, Floridamade front-page news and affected the women's movement everywhere. "The gay-straight splits" tore apart close friends and political comrades, 
and strained the capacities of those in the association and other feminist organizations to function together. "Lesbians skew the women's movement," argued a prominent New York feminist and historian. ${ }^{13}$ She was not alone; progressive women for the next few years were to argue, as Amy Swerdlow did at a women's studies meeting in Maryland to prepare for the 1975 International Women's Year conference in Texas, that no struggle should be put forward around lesbian issues; that could wait until later. While this position might be understood as a strategic move to advance the women's rights movement, it was perceived as being as much a slap in the face as when male leftists told women they would have to wait until "after the revolution." Lesbians at the Houston meeting subsequently released balloons saying "We Are Everywhere."

The backlash demonstrated that lesbians were organizing and becoming more visible, putting forth an analysis of heterosexism and capitalist patriarchy. For me, the task of bringing lesbian visibility to the movements and building inclusivity in Women's Studies meant continuing to organize in many places at once. I participated in a number of radical and professional association conferences, helping to organize caucuses within existing organizations, and to bring new members to NWSA. For the Berkshire Women's History Conference in 1978, for example, I organized the first lesbian theory session, which created quite a stir. A newly formed caucus read a statement at the end of the session, a large meeting was held, a Press Statement issued, and plans for future work emerged..$^{14}$ Many lesbians found community, strength, and support through such organizing to do lesbian research. Lesbian researchers and lesbian study groups began to meet, for among lesbians together there was less necessity to defend one's work as scholarly or significant. Despite the fact that it was not popular to critique other feminists, the caucus's criticisms of the absence of lesbian materials were not entirely unfounded.

Even within feminist organizations and women's studies venues, lesbian activism, and even lesbian scholarship, were not often considered legitimate..$^{15}$ The few lesbians doing lesbian research did it in relative isolation. In a phone conversation planning for the 1979 Kansas conference, for example, Barbara Smith said, "Lorraine Bethel, Gloria Hull and myself are the only black lesbians in the country doing research on women's issues" (Farley 1979b). ${ }^{16}$ When we were able to share our work, we became targets for homophobia and were shocked by a punishing backlash the intensity of which it is difficult today to convey. Some lost jobs. Some lost friends. But, amazingly enough, we were doing it. And the lesbian caucuses, regional as well as national, played an important role in challenging the listening spaces not only within the new field of Women's Studies but in the academic and public settings in which women's studies work was being carried and where, all too often, lesbians were lightning rods for reaction.

One of the first tasks the New York region undertook at the instiga- 
tion of the New York Regional Lesbian Caucus, for example, was the development of a defense committee to support the co-coordinator of the Women's Studies Program at Brooklyn College in a tenure fight. Since she also taught lesbianism courses at Barnard and Brooklyn Colleges, the legitimacy of Women's Studies and of lesbian studies were joined in this case. At a 1977 public symposium at City University of New York, "The University: Frontier or Backwater for Feminism?" women's studies faculty, staff, and students from across the state came together to successfully defend her job. It was my job; I was given tenure without being promoted, for Women's Studies was just beginning to prove itself a legitimate academic field. "How can you, as a lesbian, claim to do research?" I was asked at the university-wide promotions and tenure interview.

How could I claim to do research, if research was understood as being objective and I was by definition biased? Research by the other was challenging our understanding of how knowledge had developed over centuries in the Western tradition of rationalism. Already, feminists had challenged the notion of an objective view untainted by bias, noting that the norm is actually a Eurocentric, male supremacist perspective that renders women and people of color off-norm. But within the feminist movement, heterosexual women of all races, and white women of all sexual identities, were challenged as well. Most of us discovered the ground that would be accepted, and the ground that would be trampled, often shifting from one locale to another. Those of us who occupy the intersections of multiple discourses may come to a theoretical position that acknowledges how different ways of looking can affect what appears as the real, and try practically to put that understanding into practice. This is never easy with automatic operating systems on. Thus, in the academy, the problematic of asserting one, universal reality has become an important means of decentering oppressive centrality. Those whose position rarely shifts may find strength in claiming to have a handle on "reality." Some tensions in the "theory debates" might be eased if differences are situated within the context of a social stratification that shapes embodied discourse. Embodied discourse includes not only beliefs or world views, hopes, and fears, but also, as embodied and operating in the automaticity of our bodies, is manifest in how we feel and see things, how we act and react, how we listen and interpret in ways that feel like what is real yet which can shift and change.

The activity of bringing forth lesbian voices occurred in multiple locations, exhilarating for those speaking up and disquieting for those listening, at least at first. None of the feminist (as opposed to explicitly lesbian) journals had yet published anything lesbian, and in setting after setting, I recall pushing for an opening in editorial policy. Given the rapidity with which we were coming out, it seemed like too long before this situation changed. For the most part, lesbians self-published splendid journals 
like Sinister Wisdom, Conditions, Amazon Quarterly, and Feminary. We circulated mimeographed materials, poems, papers and course syllabi, manifestoes, position papers, and collective statements. Some letters, a dozen pages long, were a much-needed outlet for lesbian scholars isolated in their work. The Lesbian Caucus made efforts to collect and make available such materials. Such tasks had been delegated to the regions and caucuses at the Milwaukee CC (1977), but the CC was unable to supply the resources to fulfill them properly. Some gains were made, of course, and our efforts were to be given an enormous boost after Lesbian Caucus member Peg Cruikshank undertook the project of producing a collection of articles and resources which was subsequently published by The Feminist Press in 1981 as Lesbian Studies. Feminists of color, some of them lesbians, were also forging new paths in scholarship, including Pat Bell-Scott, Gloria Hull, and Barbara Smith's important anthology, All the Women Are White, All the Blacks Are Men, But Some of Us Are Brave: Black Feminist Studies, also published by The Feminist Press (1981).

\section{Continuing the Struggle Within NWSA}

The second CC meeting, in May of 1978, took place in a "women's space," a barn that had been made over by a Minneapolis women's collective into Maidenrock, a women's institute with bunk beds and meeting space in a natural country setting. Maidenrock was an example of the kind of woman-centered institutions that combined feminism and lesbianism. For a time there appeared no difference between, for example, women's music and lesbian music, but as that cohesiveness became apparent, women's culture and women's space came under suspicion and criticism in some quarters. Straight women feared being tainted lavender, and women of color feared being set against men in the face of racism affecting both men and women. Simultaneously, racism, homophobia, and an emergent—and contested-politics of difference operated, breaking down claims about women as a unified category even as they were being put forward in a struggle against oppression. This dynamic became evident at Maidenrock. Members of the CC were subsequently told that Third World women did not feel comfortable in non-urban settings. Its having been designed as a woman's space discomforted some as much as it delighted others. Some might have shied from going to a predominantly lesbian space; others might simply have objected to a woman-only space. ${ }^{17}$

In addition to the business of the association, the CC members spent hours doing consciousness-raising $(\mathrm{C}-\mathrm{R})$ on racism and resolved that at the next CC we would do C-R on homophobia. While these measures were not universally approved of or liked, and were actively resisted by some, the effort was important in tackling emotionally charged and crucial issues, 
albeit without resolving them. Discussions of racism were challenged by those unused to thinking of (their) race, and similarly, discussions of homophobia were resisted, especially by those who needed their protection.

NWSA was relatively unsuccessful in resolving the original rift in the early years between Third World women and the other women on the CC, and between lesbian and Third World women. It also failed to structurally assist alliances rather than set up competition for scarce resources. Separate and overlapping caucuses exacerbated this rift, which most penalized lesbians of color, the most contested and un(der)represented group, and the least visible. What the association came to call scheduling overlap actually constituted the structural invisibility of lesbians of color as a group. Finding time before meetings for identity caucuses to meet-and especially finding times that did not pit the Lesbian and Women of Color Caucuses against each other in the same time slot and continue to penalize lesbians of color-was an ongoing issue in NWSA for decades. It was never easy for caucuses to make policies like this in the association. Every year the Lesbian Caucus had to raise the same concern.

As a result, the association did not benefit as fully as it might from strong caucus critiques uniting and combating racism and homophobia, weaknesses for which the association and its members were to continue to suffer. Speaking up at all was a problem; burnout was a reality. Too many were being torn. Nevertheless, at caucus meetings for women of color and lesbians, many often gained a sense of strength and support. The perennial problems persisted; yet, when called upon in plenaries to speak as a member of a constituency to the association as a whole, white lesbians, women of color, lesbians of color, and other constituents contributed exciting, provocative, and rich addresses over the years.

During the two years between the founding convention and the first membership conference, NWSA met only as regions and as the CC. In the first year the Lesbian Caucus Newsletter reported under "Regional News":

The lesbian caucus met and wrestled with the problem of moving from feminist to lesbian feminist activism. What seemed to be a conflict between personal and task orientation in the meetings was in fact the stated need of the group to build safe space together, to find ways to come out or to assume leadership as lesbians within the women's studies movement. We agreed to meet therefore one day before conferences are scheduled to begin in the future. This will allow us to give energy to each other as individuals so that our workings as a caucus will have this base. It was difficult to convey this necessity at the business meeting, but after lengthy discussion, the group [the New York Region] agreed to sponsor and defend this practice by advertising future NY Region Women's Studies Conferences in this way. Also consciousness raising sessions will be held during the conference for all interested in exploring ramifications of sexual identity to our work in the movement. $(1977,3)$ 
In general, within the NWSA, there were tensions between the more traditional, regional forms and the more radical, constituency-based structures. In struggles over priorities and needs, the constituency-based caucus structures were in the minority position. The national didn't provide, except, importantly, to the Third World Women's Caucus, funding to the caucuses at all in the early years. The regional women's studies associations rather than the national office were charged with supporting caucuses financially. In the struggle to prioritize practically nonexistent funding, the Lesbian Caucus was substantially without funds for the early years. Its representatives were strained. Buenaventura dropped out the first year; McNaron the second year; then Cayleff after the 1979 CC meeting. ${ }^{18}$

Moreover, many lesbians simply were not out. In Lesbian Caucus meetings of professional associations, and of NWSA regionally, early on, when I looked hopefully among these active and capable women for volunteers to do the work that needed to be done, I was surprised by their passivity. At first I couldn't understand it. Did they just enjoy getting together, but want someone else to do the work? Outside the rooms, they were leaders. What was going on? I decided that this reticence was a function of oppression. They could be leaders for women, but being leaders for lesbians was still taboo (see Farley 1981). One of the reasons we needed to organize lesbians in the first place was that it was still so hard to be out at work and even in the movements. It wasn't that the women at our meetings couldn't do the work; it was that they felt they couldn't do it and survive.

By the time of the first conference in Kansas, in June 1979, I was the only active Lesbian Caucus representative available to do all the work that needed to be done. Correspondence reveals the high expectations of lesbians around the country. It was exciting to meet whether in person or by mail-and each letter was handwritten or typed on an old-fashioned typewriter without erase keys! And how high the hopes were: Please send money to fund our collective to do a workshop in Kansas. Please send copies of your files on lesbians. Here were other versions of the perception that once institutionalized as a caucus, we were powerful, rich, and very organized.

Still, the 1979 newsletter report to the caucus reveals that by the time of the first NWSA conference in Kansas nearly two years after the founding convention, a good deal had been accomplished: a bibliography was available; regional caucuses had formed; women were publicly doing lesbian research despite its dangers for a career, even teaching lesbian materials and lesbian courses; newsletters and relevant materials were circulated; lists had developed that allowed mailing to go out to members of the caucus and be withheld from the national office for those still needing privacy; and workshop proposals were generated for the national conference. ${ }^{19}$ 
While it might appear that professional associations in the disciplines were more in need of the corrective agency of constituency caucuses than an interdisciplinary feminist association whose members already had taken the risk of building outside the traditional professional and disciplinary venues, those lesbians who remained active as advocates within the NWSA keenly felt the pinch of homophobia, however unconscious. It strained friendships and professional bonds. Even lesbians in NWSA, such as regional reps who happened to be lesbians, participated in the silencing. "There was a level of distrust and discomfort that was paralyzing," Cayleff recalls (see Farley 2001). While later the same lesbians who put up roadblocks to lesbian advocacy themselves became advocates, in the early years especially, it was more normal to do regional business than caucus business, and to distance from the political concerns of lesbian advocates.

In the CC, there was no agreement over whether or not the caucuses should or needed to play an advocacy role. There tended to be a kind of tokenism operating to undermine the caucuses. If a student or a lesbian or a Third World woman was around, she was regarded as a caucus representative whether she was or wasn't. If she was a regional representative, she might not have been dealing with issues of how to build and support constituency groupings within the NWSA, so she might not respond with a sense of caucus priorities. Issues of homophobia and racism were pretty much swept under the rug within the CC and association hierarchy including the association newsletter (Farley c.1980).

To fulfill the charge made at the Maidenrock CC to explore and combat homophobia in the association, at the 1979 CC meeting in Bloomington, Indiana, Charlotte Bunch was brought in as a neutral, outside expert on homophobia. She spoke generally about homophobia as a phenomenon that occurred "out there," thereby allowing discussion of homophobia in the association to be avoided. Because Bunch was an experienced activist, we were subsequently able to explain to her that she was, in effect, functioning as a shield for internal homophobia while pointing the finger outside the association. Nothing changed; the CC continued to act as though it need not concern itself with homophobia or develop strategies for sensitivity in its processes.

At that same council meeting, caucus issues and the lesbian representatives were passed over, ignored, and silenced. While the lesbian representatives caucused on association business outside the meeting room-which was fully known and understood inside the meeting room-the CC, chaired by a Midwest representative, who happened to be lesbian, moved forward on business relating to the caucuses. When we returned and discovered the issues had been decided in our absence, I brought it up only to be treated as though I just had a personal problem. "Why did Pat G think I raised that as 'personal' item?" I scribbled to the other lesbian representa- 
tive, Susan Cayleff, on the back of the Rocky Mountain/Southwest Report to the CC. We had all learned about homophobia. Why wasn't our legitimate political concern taken as such, by the body as a whole? Cayleff and I continued to scribble notes, trying to figure out what had happened and what to do as the business of the meeting continued. ${ }^{20}$ Cayleff sensibly suggested we tell the CC that their move was "indicative of the tensions/ unspoken struggles that are ongoing," ask for the rationale, and request a reopening of the discussion. ${ }^{21}$ It didn't work.

Whatever rationale the CC might give, such as time or efficiency, that rationale would operate to constitute their reasonableness, and to have them continue reasonably to sweep aside the lesbian concerns. This was very much business as usual. Especially given the education session on homophobia in the academy, it felt punitive and even crazy-making, as though the ones proceeding were the Important and Responsible Ones: other concerns and input need not be heard. ${ }^{22} \mathrm{I}$ felt thrown back at that moment to the first CC meeting, when the council had kept going despite concerns about racism, only this time it was the lesbian caucus representatives who were being silenced: "I FEEL exactly like the Third World Women," I had written in my notes of the Bloomington meeting. It was not just that the same person was chairing, although appeals to her made it worse, for she felt at that time she had to distance herself from us. "Don't talk to (at) E," say the same notes. This had to be a group dynamic, one person could not have accomplished it by herself. The room had acted, and had been able to set aside objections, constituting itself as arbiter of the important, the acceptable, the reasonable, the real.

I say "the room," but I mean the discourse that defines these things. The predominant discourse of those days assumed one reality and allowed for no understanding of different interpretations, creating an Us and a Them, with the constituencies, constituted by the caucuses, expendable. At the time, should there be disagreement rather than unity within an identity constituency, the question could be raised whether there existed a constituency at all. Someone else of that identity could answer and render the caucus representative invisible and unnecessary, or both, rendering the notion of constituency caucuses ineffectual or unimportant-all with no political discussion. ${ }^{23}$

I would later summarize caucus/association dynamics and questions of racism and homophobia:

Internally these issues surfaced on a working basis over decisions on budget priorities, decision-making (and hiring) procedures, Newsletter relations with NWSA-power issues in building themselves, the Newsletter, the National Office and even regional CC representatives tended to neglect ways to support caucuses, primarily lesbians, students, staff women, Pre K-12 or relegate them to lower priority. (c.1980) 
In the listening space of that meeting, I, articulate, outspoken, strong, felt inarticulate in that nothing I said or did could be heard, that I couldn't both appear reasonable AND invent a way to stop the ongoing meeting, and that I thus felt powerless to affect the room. And I recalled sensing the women of color may have experienced a similar positionality. I felt as I imagined they might have felt. It wasn't that I WAS/we WERE inherently unable to be effective. Ineffectiveness doesn't reside in our characters as an essential property trait. In that space at that time given those dynamics, that is too often how we were constituted.

\section{Conclusion}

Others may see such moments differently, experience them differently, see $\mathrm{me} / \mathrm{us}$ differently, and experience me/us differently. True. What is seen is always being seen through various lenses, and we may experience more or less community in these interpretations. What interests me about these meeting notes-I well remember the despair I felt sitting in that room-is that they indicate a reprise, with a difference, of the first CC meeting. The concern that time had been racism. The experiences of the women of color had never been aired, understood, redressed. Now it was lesbians. There was something about the prevailing discourse in which our academic work, and in the early days, our movement work, was grounded that called for a unified view which authorized and composed the reasonable and an (irrational) other that challenged it: things had to be "either/or," and there wasn't much room for "both/and."

And those, to me, who have been most articulate over the years, have been those who belong in both othered categories and defy the requirement to be either this or that, who are able to shift the listening spaces that operate to silence their voices by coming together and speaking out despite them, articulating other versions of reality. This is what shifts discourses, affecting the automatic listening spaces within which we act enough so that a space for difference can emerge. This starting place allows us to live in difference as soon as we let go of the need for certainty, absolute authority, and non-negotiability that constitutes a claim to be objective. These are some of the hard lessons I learned as a lesbian up against and participating in fundamentalist discourses of rationalism that breed racism and homophobia (Farley 1984). Because our discourses operate automatically at the embodied level, in our guts, our throats, our nervous systems, this automaticity is a combination of word and flesh, and can change-and with it our sense of possibilities. Structural tensions between regions (considered normative), the newsletter, and caucus constituencies (considered marginal) provided a ground upon which discourses of homophobia and racism became manifest in the early years of the NWSA. That is the basic structural tension upon which the other tensions fed. 
In NWSA, there would always be some women of color, including lesbians, and other lesbians who would be able to function amid these dynamics at some level. It would be less difficult for white lesbians because of the always already operating "business as usual" dynamics that put white and heterosexual at the center and made others strange, off the point, to be included (or not, if it wasn't efficient or timely or appropriate to the "central" concerns). White lesbians nonetheless found it difficult to confront racism, but I know I found it more difficult not to, largely due to the courage of women of color who spoke to my face, and who wrote. Thus, I do find hope for change, in automaticity of our discourses, embodied and operative as daily life. In feminist organizations there is at least some talk about it all; and perhaps, over time and with the courage of sisters, we hear, we see, we shift. We may even learn to forgive ourselves and others. I have faith in the love of women.

Tucker Pamella Farley teaches graduate and undergraduate courses at Brooklyn College, CUNY. She began teaching Women's Studies in trade unions and the academy in 1970, co-coordinated the first women's studies program in New York, helped found and administer the NWSA, the Lesbian Caucus, and NYWSA, and participated in the founding editorial board of the NWSA Journal. She has been an active participant in interdisciplinary feminist associations and study groups, and teaches interdisciplinary theory courses in the Honors Academy and the Ford Scholars Program at CUNY. Currently she is working on Discourse, Objectivity and Science. She has written on Virginia Woolf, feminism and theory in feminist journals and anthologies including The Politics of Women's Studies; Contemporary Lesbian Writers of the US; The Future of Difference, WRB, NWSAJ, LRB. Send correspondence to 45 Grace Court 6 C, Brooklyn, NY 11201; tpfarley@brooklyn.cuny.edu.

\section{Notes}

1. A student, Susan Cayleff, and a faculty member, (Tucker) Pamella Farley, were asked by the newly formed caucus to address the body. This event was so vividly and enthusiastically recalled by lesbians interviewed twelve years later at the tenth anniversary conference of NWSA at Emory College in Atlanta, that the video of those interviews came to be titled A Call to Rise and the event was repeated at a plenary to enthusiastic and prolonged applause (Farley and Pollack 1999).

2. The letter goes on: "We don't have an 'official' Lesbian Caucus statement of purpose. We have some policies that we've voted and implemented; though not written bylaws, they have come out of the history of the caucus and the resolutions forming and shaping it" (see Farley c. 1980). 
3. A first revision of the constitution was approved in Austin in 1992, though the structure was strengthened in Oswego in 1998. At this twentieth anniversary conference, a modification was made that gave voting rights to committee chairs, but left the same number of caucus and regional representatives-redistributed from three caucus/two region to four caucus/one region, with permanent representation for the chairs of both lesbian and women of color caucuses (Zimmerman 2001).

4. The phrase is borrowed from the title of a poem by Joan Larkin (1975). In an earlier version of the history of NWSA and the Lesbian Caucus for an NWSA volume edited by Kay Townes, I was conscious of how much I was not saying. Here, I wonder if I am saying too much; yet, should what is said here not be told, be "hidden from history"? [The phrase is borrowed from Sheila Rowbotham.] I am indebted to the many people who contributed to this effort, especially to Beverly Horton, who worked in the files of my archives, read this piece, and offered comments.

5. Barbara Gerber recalls that Sybil Weir and others "smoothed it over" (2001).

6. There were at least two regional women's studies associations at the time, one on the west and one on the east coast, where there had been a good deal of discussion about whether to build a national association from the ground up by developing Women's Studies at the grass roots (a position advocated by the Women's Studies Program at SUNY Buffalo, for example), or to start an association at the national level and grow from there. An entire track of the weekend conference, "Strategies for Survival," held at Brooklyn College, had been devoted to this discussion in 1974-1975 (See Farley 2000).

7. Having been otherwise occupied until 18 May, Gonzales sent a late mailgram, to which Barbara Dubinsky, NYT Magazine "Letters" editor, replied (correspondence in Farley archives), saying they had already run a series of responses 10 April. Among those printed responses was one by the co-executive directors of The National Gay Task Force.

8. Howe had proposed that NWSA fund a section of the Feminist Press Women's Studies Newsletter; while it was wonderful to have an important task like our NWSA publication and communication media handled by an expert, assuming the financial burdens of an already developed vehicle was more problematic. Then Howe proposed that NWSA take over the full responsibility of funding the newsletter, as well as establishing a national office with a paid executive director at a salary competitive with that of the executive director of MLA. The fledgling association nearly went under with these financial burdens, and a few years later had to return to volunteer staffing for a period. Most of the Lesbian Caucus members consistently opposed the new association taking on such steep financial burdens without a firm financial basis to support them. 
9. I wrote to Pat Gozemba, who co-authored a response from the caucus, "There will be three letters which Florence says are a packet and can't be broken up. (I said one should be from the lesbian caucus, she said I was bullying her and trying to get her to be undemocratic) and that furthermore, the newsletter staff made a decision on the letters (re they are not NWSA material), though she first implied they were. I said NWSA should have a response to Roiphe" (1977). The December 1977 Lesbian Caucus Newsletter says: "Most of you have read the Women's Studies Newsletter column printing letters of response to the Roiphe attack on lesbians at Sarah Lawrence. This column was represented variously as the response of the Newsletter staff, separate from the NWSA and thus not to be edited by the NWSA, and as the response of the NWSA. . . To prevent Newsletter editorial decisions that exclude caucus material, and to give each caucus some space in the newsletter as we suggested at the Milwaukee CC, the Steering Committee resolved, and the newsletter advisory committee agreed, to have a rotating caucus column in the Women's Studies Newsletter. We are soliciting contributions for our caucus column" $(2-3)$.

10. In a letter talking about the caucus for subsequent representatives I wrote, "A committee was in charge of Newsletter (Florence's) input, but we had a lot of trouble both getting printed what was submitted and having our representative (Susan) notified of Newsletter Advisory Committee meetings and work. She never was included, really" (See Farley c.1980).

11. "It seems at least minimal to print both the thoughts of lesbian and heterosexual feminist women re the matter of anti-lesbian backlash. I'll look for the comparative reasoning that might be at the basis of Florence's decision to exclude lesbian-written material when I read the articles which are to be printed" (See Elizabeth 1977).

12. Florence Howe sent a letter questioning lesbian caucus resolutions; they were not printed. (1977).

13. Roz Baxandall, at a meeting of Marxist Feminist Group One, describing the impact of lesbians coming to organize lesbians in a women's movement that saw heterosexual women's concerns in relation to men as central.

14. The press release summarizes criticisms made of the heterosexist bias in the make-up of the conference; offers a conciliatory olive branch to lesbians within the organization; and boldly states: "The statement [read at the close of our scheduled lesbian theory panel, "Power, Oppression and the Politics of Culture,"] affirms that acknowledgment of the existence of a distinct lesbian culture and history threatens the institution of heterosexuality and raises questions about why this fact has not seemed self-evident to non-lesbian historians." This tone, and criticism of the conference, was balanced by "[A]ppreciation of the long history of the Berkshire Conference of Women Historians, of the visible advocacy of lesbian history by members of the 
Conference, and of the continued openness of their recent conferences to all those involved in women's issues." The Press Statement was signed by Libby Bouvier, Chris Czernick, Debbie Edel, Ellen Mutari, Frances Doughty, Joan Nestle, Clare Potter, Judith Schwarz, Tracey Wren Setel, Barbara Smith, Sandi Stein (25 August 1978).

15. If "scholarly" and "feminist" were practically oxymoronic, then lesbian feminist was too much. Our 1978 Berkshire Women's History Conference session, "Power, Oppression and the Politics of Culture," with presentations by Audre Lorde, Emily Jensen, Barbara Smith, and Pamella Farley, was proposed as a special section of Feminist Studies, but rejected as not being scholarly enough. At a national conference, with no dissenting voice, a popular feminist Virginia Woolf scholar labeled lesbian criticism of Woolf as gutter conversation. Such examples were pervasive.

16. Smith was not alone in feeling isolated. Judith Schwarz wrote sophisticated analyses in streams of handwritten pages. JR Roberts wrote that she was working on a bibliography of black lesbians (See Farley 1979b; Schwarz 1978; Roberts 1979).

17. Months before, Audre Lorde had declined to attend Maidenrock because as the mother of a son she would not support a place that might exclude his gender. Lorde and I were members during this period of the same women's circle in New York, and she introduced me to Barbara Smith as I was putting together a lesbian session for the Berks in 1977. As a member of the Combahee River Collective, Smith helped author the "Black Feminist Statement" which holds as true today as it did then in 1981).

18. It must also be said that the costs of participation were prohibitive for students, which was stunting and led to a sense of disenfranchisement (See Farley 2001).

19. "After collating, synthesizing, and developing proposals for participation in the four sessions the caucus has been allocated for the conference in Kansas, we have devised four thematic divisions: Lesbian-Feminist Projects: Community Alternatives; Curriculum and the Classroom Experience; Teaching and Researching Lesbian History; Lesbian Culture: Our Voices. In addition to the sessions sponsored by the caucus, several were passed on to the planning committee by Feb. 1. The caucus recommends as well that constituencies be included as part of the wrap-up of the conference, giving concrete shape to and support for the caucus constituencies within the association as they are revitalized by the conference this spring." NWSA Lesbian Caucus Report (February 1979, 2).

20. "Claire says she brought up that we weren't here, and it was replied that the discussion had been announced. That feels punitive to me. Analysis-L.C. reps = irresponsible; we are responsible. We'll just go on without them. (Show 
them.) Am I nuts. It looks to me like some of the women here feel guilty" (See Farley and Cayleff 1979).

21. "Why don't we just ask what was the rationale behind proceeding without us since we obviously weren't here because of generally understood reasons. Was it punitive.

"We'd like to make a statement and reopen discussion on caucuses.

"Was a vote taken to proceed without the 21 . c. reps. It seems indicative of the tensions/unspoken struggles that are ongoing. <-(to be said to cc)" (See Farley and Cayleff 1979).

22. "Whatever their rationale was (time, efficiency, whatever ie AS USUAL) its effect was punitive.

I FEEL exactly like the $3 \mathrm{WW}^{\star}$ who, when they came back to the meeting, (apparently found no space to function in \&) sat silent and refused to do the work of the assn.

I'm not sure I feel this space is one I can talk constructively in. I might later. How about you? Better to do right now \& insert (try to) ourselves? Christ, they already said and acted on that they didn't give 2 shits. About hearing our input on caucuses." (Farley and Cayleff 1979)

23. Pointing to "Divide and conquer" with an arrow: "leads to ... Do we represent a constituency if some other lesbians disagree with us" (See Farley and Cayleff 1979).

\section{References}

Bell-Scott, Pat, Gloria Hull, and Barbara Smith. 1981. All the Women Are White, All the Blacks Are Men, But Some of Us Are Brave: Black Feminist Studies. New York: The Feminist Press.

Brown, Susan, Elisa Buenaventura, and Pat Gozemba. 1978. Personal correspondence to Susan Cayleff and author. 3 January. Farley Archives. Cultural Studies/Queer Studies, Brooklyn College, Brooklyn, NY.

. 1977. Unpublished article. Farley Archives. Cultural Studies/Queer Studies, Brooklyn College, Brooklyn, NY.

Combahee River Collective. 1983. "The Combahee River Collective Statement." In Homegirls: A Black Feminist Anthology, ed. Barbara Smith, 272-82. New Brunswick, NJ: Rutgers University Press.

Buenaventura, Elisa. 1978. Personal correspondence to Elaine Reuben, members of the Steering Committee, the Coordinating Council, and the Lesbian Caucus. 1 May. Farley Archives.

Cruikshank, Peg. 1981. Lesbian Studies. New York: The Feminist Press.

Elizabeth, Anne. 1977. Personal correspondence to author. 15 August. Farley Archives.

Farley, Tucker. 2001. Telephone conversation with Susan Cayleff. 1 March.

. 2000. "Changing Signs." In The Politics of Women's Studies: Testimony 
from Thirty Founding Mothers, ed. Florence Howe, 264-75. New York: The Feminist Press.

- 1993. "Deconstructing the Absolute." In Contemporary Lesbian Writers of the US: A Critical, Bio-Bibliographic Source Book, eds. Sandra Pollack and Denise Knight, xxi-xl. Westport, CT: Greenwood Press.

- 1980. "Lesbianism and the Social Function of Taboo." In The Future of Difference, eds. Hester Eisenstein and Alice Jardine, 267-73. Boston, MA: G.K.Hall. c.1980. Personal correspondence to Mirtha Quintenales. CC: Charlotte, Elizabeth, Nan, Barbara, Anastasia, Mae. Farley Archives. Farley Archives. Cultural Studies/Queer Studies, Brooklyn College, Brooklyn, NY.

- 1979a. Notes on author's report to the Kansas Lesbian Caucus. Farley Archives. Cultural Studies/Queer Studies, Brooklyn College, Brooklyn, NY. . 1979b. Notes on author's telephone conversation with Barbara Smith. Farley Archives. Cultural Studies/Queer Studies, Brooklyn College, Brooklyn, NY.

. 1977. Personal correspondence to Pat Gozemba. Summer. Farley Archives. Cultural Studies/Queer Studies, Brooklyn College, Brooklyn, NY.

Farley, Tucker, and Susan Cayleff. 1979. Handwritten notes. Bloomington, IN, CC. Farley Archives. Cultural Studies/Queer Studies, Brooklyn College, Brooklyn, NY.

Farley, Tucker, and Pollack, Sandra. 1999. A Call to Rise. Video cassette. Prods., Tucker Farley and Sandra Pollack, New York. Farley Archives. Cultural Studies/Queer Studies, Brooklyn College, Brooklyn, NY.

Gerber, Barbara. 2001. Telephone conversation with the author. 1 March.

Howe, Florence. 1977. Personal correspondence to author. 12 October. Farley Archives. Cultural Studies/Queer Studies, Brooklyn College, Brooklyn, NY.

Larkin, Joan. 1975. "Some Unsaid Things." In her Housework, 50. Brooklyn, NY: Out and Out Press.

Lesbian Caucus Newsletter. 1977. December. Farley Archives. Cultural Studies/ Queer Studies, Brooklyn College, Brooklyn, NY.

McNaron, Toni. 2001. Telephone conversation with the author. 9 February.

Press Statement. 1978. Signed by Libby Bouvier, Chris Czernick, Deb Edel, Ellen Mutari, Frances Doughty, Joan nestle, Clare Potter, Judith Schwartz, Tracey Wren Setel, Barbara Smith, Sandy Stein. 25 August, Farley Archives. Cultural Studies/Queer Studies, Brooklyn College, Brooklyn, NY.

Roberts, J.R. 1979. Personal correspondence to author. 21 January. Farley Archives. Cultural Studies/Queer Studies, Brooklyn College, Brooklyn, NY.

Roiphe, Anne. 1977. "The Trouble at Sarah Laurence." New York Times Magazine, 20 March.

Schwarz, Judith. 1978. Personal correspondence to author. 5 December. Farley Archives. Cultural Studies/Queer Studies, Brooklyn College, Brooklyn, NY.

Zimmerman, Bonnie. 2001. Note to author. 28 June. Farley Archives. Cultural Studies/Queer Studies, Brooklyn College, Brooklyn, NY. 